\title{
PENTINGNYA KONSEP DASAR MATEMATIKA PADA KEHIDUPAN SEHARI-HARI DALAM MASYARAKAT
}

\author{
Juliana Tampubolon ${ }^{1 *}$, Nurdini Atiqah², Unedo Immanuel Panjaitan ${ }^{3}$ \\ Program Studi Matematika Universitas Negeri Medan \\ *Email : julianatampubolon9@gmail.com
}

\begin{abstract}
Abstrak
Matematika terbentuk dari hasil pemikiran manusia yg berhubungan dengan ide, proses, dan penalaran. Menyadari arti pentingnya matematika tersebut, maka matematika dirasakan perlu buat dipahami serta dikuasai sang segenap lapisan masyarakat, terutama peserta didik-siswa Sekolah Dasar sampai PTN. Metode yang dilakukan ialah memakai penelitian Historis dan juga Kualitatif. buat membuat matematika bisa digemari poly kalangan, kita harus menghasilkan anak-anak tertarik buat belajar matemaika. salah satunya artinya memakai manipulative. Belajar matematika menggunakan manipulatif dapat membantu anak-anak dalam membangun konsep dasar matematika serta bagaimana mereka mengaplikasikan pengetahuan mereka pada kehidupan sehari- hari. Kognitif psikologi telah menggambarkan beberapa langkah cara terbaik dalam membuatkan pengalaman belajar matematika.
\end{abstract}

\section{Abstract}

Mathematics is formed from the results of human thinking related to ideas, processes, and reasoning. considering the importance of mathematics, it is mathematics that needs to be understood and mastered by the community, especially elementary school students to state universities. The method used is historical and qualitative research. To make mathematics liked by many people, we must produce children interested in learning mathematics. one of which means using manipulatives. Learning mathematics using manipulatives can help children in building basic mathematical concepts and how to apply their knowledge in everyday life. Cognitive psychology has described some of the best ways to create a mathematics learning experience.

Kata Kunci : Manfaat belajar matematika, konsep, pemecahan masalah 


\section{PENDAHULUAN}

Matematika adalah ilmu yang sangat berguna bagi kehidupan kita sehari-hari. [1] mengungkapkan bahwa matematika adalah ilmu yang membahas pola atau keteraturan (pattern) dan tingkatan (order). Dalam hal lainya dibagikan bahwa sekali lagi hal ini memberikan bahwa pengajar atau guru matematika wajib memfasilitasi siswanya untuk belajar berpikir melalui keteraturan (pattern) yang ada dengan bisa mengetahui pola matematika ini maka dibutuhkan pendidikan dalam mencapainya. [2] mengatakan bahwa pendidikan ialah usaha sadar serta terencana untuk mewujudkan suasana belajar dan proses pembelajaran agar peserta didik secara aktif mengembangkan potensi dirinya untuk memiliki kekuatan spiritual keagamaan, pengendalian diri, kepribadian, kecerdasan, akhlak mulia, serta keterampilan yang diperlukan dirinya, masyarakat, bangsa dan Negara.

Penerapan matematika erat kaitannya dengan kehidupan sehari-hari. Matematika memiliki banyak fungsi, antara lain dengan membandingkan uang jajan, menghitung berat benda dan berbagai perselisihan lainnya, berperan dalam mengatasi konflik antar manusia. Pada saat ini, kemampuan matematika dan kemampuan menggunakan matematika merupakan persyaratan penting bagi umat manusia.Tanpa kontribusi konsep matematika dan proses matematika dasar, umat manusia akan menghadapi banyak kesulitan.

Oleh karena itu, manusia membutuhkan matematika sebagai alat untuk memenuhi kebutuhan hidup sehari-hari. Oleh karena itu, matematika adalah kunci untuk belajar. Jika kita melihat lebih luas, ibu rumah tangga adalah merebus air atau sayuran, yang artinya contoh sederhana penerapan konsep matematika dasar. Saat ingin menambahkan air, bumbu, dan sayuran. Anda perlu menghitung dan membandingkannya. Banyak model lain dalam kehidupan sehari-hari. Asal usul model ini adalah pembuktian konsep matematika dalam kehidupan kita bahwa kita sering menggunakan konsep matematika.

Matematika pada hakikatnya adalah segala aktivitas manusia di dalam kehidupan sehari- hari menurut ahli [3]. Menurut [4] matematika mempunyai beberapa ciri penting, yaitu: 1) Memiliki objek yang abstrak: Objekek matematika adalah adalah fakta, konsep, penggunaan dan hukuman kesemuanya itu berlaku bagian dalam 
mencanai proses. 2) Memiliki pola pikir deduktif dan konsisten: Matematika dikembangakan dedukasi dan seperangkat anggapan anggapan yang tidak dipersoalkan lagi nilai kebebnarannya dan dianggap benar, berpangkal dari hal-hal yang bersifat umum diterapkan atau diarahkan kepada hal-hal yang bersifat khusus. 3) Konsisten dalam sistemnya Dikemukakan oleh [5] bahwa dalam matematika terdapat banyak sistem. Ada sistem yang mempunyai kaitan satu sama lain, tetapi ada juga sistem yang dapat dipandang terlepas satu sama lain. Misalnya sistem-sistem aljabar dan sistem-sistem geometri untuk mempelajari matematika di sistem sehari-hari.

Telah dikemukakan [6] bahwa pola pikir matematika sebagai ilmu adalah deduktif. Sifat- sifat atau teorema yang ditentukan secara induksi atau empiris kemudian dibuktikan kebenarannya melalui langkah-langkah deduktif berdasarkan strukturnya. Ini bukan kasus matematika sekolah. Meskipun pada akhirnya diharapkan siswa mampu berpikir secara deduktif, namun dalam proses pembelajaran dapat digunakan cara berpikir induktif. Oleh karena itu, kita perlu memiliki pemahaman yang lebih mendalam tentang konsep matematika supaya kita dapat beroperasi lebih tersusun dan efisien bagian aksi sehari-hari.

\section{PEMBAHASAN}

1. Kemampuan Pelajar Sekolah dalam Mendukung Pembelajaran Matematika

Proses berpikir kreatif siswa bekoordinasi dengan pengelaman belajarnya. Menurut para ahli [7] pengalaman belajar yang diperoleh setiap siswa pastinya berbeda-beda, maka ide-ide yang digunakan untuk menyelesaikan masalah juga berbeda. Pemilihan strategi dan model pembelajaran juga dapat mempengaruhi proses berpikir kreatif siswa, hal ini sesuai dengan yang diungkapkan oleh [8], bahwa pemilihan strategi pengajaran yang kurang tepat dapat juga mengganggu proses berpikir siswa, salah satunya adalah proses berpikir kreatif.

Banyak pengetahuan dasar yang memahami konsep dasar dari materi matematika itu sendiri. Tak perlu dikatakan, kita masing-masing harus memahami konteks lebih baik daripada matematika itu sendiri. Dalam pembelajaran, aktivitas siswa lebih banyak mendengarkan penjelasan guru dan mencatat, belajar matematika langsung pada lambang- lambang. Proses pengajaran masih cenderung berpusat pada guru, dan belum banyak aplikasi yang berpusat pada siswa. Sementara itu kebanyakan 
guru dalam mengajar masih kurang memperhatikan kemampuan berpikir siswa dan metode mengajar yang digunakan kurang bervariasi [9].

Menurut [10] melalui pembelajaran kontekstual siswa mampu secara independen menggunakan pengetahuannya untuk menyelesaikan masalah-masalah baru dan belum pernah dihadapi, serta memiliki tanggung jawab yang lebih terhadap belajarnya seiring dengan peningkatan pengalaman dan pengetahuan para pelajar Dikatakan [11] bahwa matematika tidak bisa dipisahkan dari aktivitas berpikir, karena dalam proses pembelajaran matematika siswa pasti melakukan kegiatan mental atau yang disebut dengan menganalisis. Dalam menganalisis tersebut orang menyusun hubungan-hubungan antar bagian-bagian informasi yang telah direkam dalam pikirannya sebgai pengertian-pengertian. Dari penafsiran tersebut, terbentuklah komentar yang pada pengertiannya bisa ditarik kesimpulan. Dari yang dikatakaan tercatat mengemukakan bila kursus kontekstual diterapkan oleh pendidik buat memfasilitasi anak didik secara berkala serta berkesinambungan hingga bisa membuat keahlian pemecahan permasalahan siswa khusunya dalam mata pelajaran matematika hendak bertambah.

2. Kemampuan Kontekstual dalam Bidangnya Masing-Masing

a) Pemrograman

Program pc/komputer hanya memiliki satu rangka instruksi yang memusatkan pc buat melaksanakan tugas tertentu. Banyak aplikasi yang bisa dihasilkan dalam pemanfaatan pemrograman pc, ialah misalnya merupakan perhitungan matematis dalam penyelesaian kasus dalam dunia metode.

Penelitian yang dilakukan [12] menyoroti hubungan antara matematika dan kehidupan keseharian yang menekankan budaya, bahasa, dan dialog diantara siswa yang sedang belajar matematika. Hasil riset tersebut diharapkan bisa dijadikan selaku acuan dalam pendidikan matematika yang berbasis ethnomathematics supaya hasil belajar siswa bertambah. Sangat perlunya dalam pelaksanaan pengembangan serta inovasi kurikulum, pengajaran, pembelajaran guru, penggerakan dari kebijakan, serta metode buat mengkikis kesombongan, ketidakadilan, serta kefanatikan di dalam warga. Peranan ini menuntuk kita seluruh dalam meningkatkan lebih lanjut ethnomathematics di dalam aktivitas pendidikan kita. 
b) Industri Bisnis

Pentingnya peran matematika dan pendidikan matematika dalam berbagai bidang khususnya dunia ekonomi dan industri serta pendidikan di sekolah dan di Perguruan Tinggi ini juga sangat memengaruhi industri bisnis masa kini. Pemodelan matematika dari pertumbuhan dan perkembangan ikan-ikan di laut sehingga dapat ditentukan di mana dan kapan seharusnya ikan-ikan jenis-jenis tertentu yang mempunyai nilai ekonomis tinggi dapat dipanen sehingga sangat penting dalam pengambilan keputusan industri penangkapan ikan (fishery management) [13].Pemodelan ilmu hisab yang lain sebagai pemodelan ilmu hisab publikasi dedar berdarah, pemodelan ilmu hisab kelahiran gempa bidang atau perputaran tsunami bisa mengecam kelahiran epedemi atau kecelakaan dan jalan kelahiran di masa yang kelak berserempak antisipasinya. Hal tersebut akan sangat penting dalam peningkatan kesejahteraan secara tidak langsung.

c) Era Globalisasi

Dalam masa di mana hubungan dan persaingan antar manusia itu unlimited hanya dalam satu Negara atau satu wilayah tertentu saja (era globalisasi), peranan matematika dan pendidikan matematika menjadi semakin berguna [14].

Peranan matematika tersebut, terutama sebagai sarana berpikir ilmiah oleh [15] disebutkan dapat diperolehnya kemampuan-kemampuan sebagai berikut :

1. Menggunakan pemahaman yang efektif. Yang termasuk konteks ini adalah kemampuan yang antara lain adalah melakukan operasi hitung, operasi himpunan, dan operasi lainya. Juga menghitung ukuran tendensi sentral dari data yang banyak dengan cara manual.

2. Melakukan manipulasi secara matematika. Yang termasuk kedalam kemampuan ini antara lain adalah menggunakan sifat-sifat atau rumusrumus atau prinsip-prinsip atau teorema-teorema kedalam pernyataan matematika

3. Mengorganisasikan data. Kemampuan ini antara lain meliputi : mengorganisasikan data atau informasi, misalnya membedakan atau menyebutkan apa yang diketahui dari suatu soal atau masalah dari apa yang ditanyakan 
4. Memanfatkan simbol, tabel, grafik, dan membuatnya. Kemampuan ini antara lain meliputi : menggunakan simbol, tabel, grafik untuk menunjukan suatu perubahan atau kecenderungan dan membuatnya.

5. Mengenal dan menemukan pola. Kemampuan ini antara lain meliputi : mengenal pola susunan bilangan dan pola bangun geometri.

3. Konseptual dalam Mengembangkan Dasar Matematika

Pembelajaran kontekstual atau Contextual Teaching and Learning (CTL) artinya konsep yang membantu pengajar mengaitkan antara materi yg diajarkannya menggunakan situasi dunia konkret dan mendorong siswa menghasilkan korelasi antara pengetahuan yang dimilikinya menggunakan penerapannya pada kehidupan mereka menjadi anggota famili serta warga [16]. Makna ini bisa diperoleh jika siswa menghubungkan muatan akademis dengan konteks asal kehidupan sehari-hari mereka. Konteks pada hal ini dapat dipamahi menjadi pola hubungan-korelasi di dalam lingkungan langsung para pelajar.

Terdapat dua tipe awam koneksi matematik menurut NCTM [16], yaitu modeling connections dan mathematical connections. Modeling connections merupakan korelasi antara situasi persoalan yang timbul pada dalam global nyata atau pada disiplin ilmu lain dengan representasi matematiknya, sedangkan mathematical connections artinya hubungan antara dua representasi yang ekuivalen, dan antara proses penyelesaian dari masing-masing representasi. kedua koneksi tadi diilustrasikan seperti gambar berikut adalah:

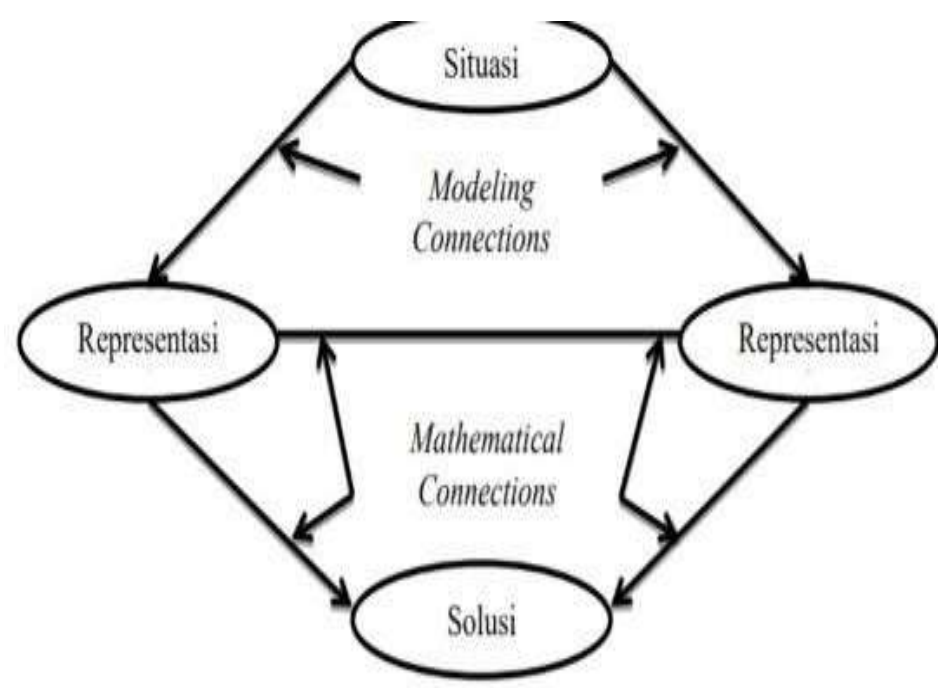


4. Konsep Manulatif dalam Mengembangkan Konsep Matematika

Dari ekspresi di atas dikemukakan bahwa pentingnya meninjau konsep matematika itu sendiri, yaitu di mulai dari pembelajaran di sekolah. Untuk mengurangi kesulitan murid dalam pembelajaran geometri, diperlukan adanya tipu penatar dalam menggunakan tata cara mengajar dan media pembelajaran yang dapat memenuhi tuntutan kebutuhan siswa dalam belajar sesuai dengan tahap perkembangan inteletual. Guru dituntut untuk menggunakan metode yang bervariasi tidak hanya ceramah saja, tetapi juga metode lainnya yang lebih menekankan pada pembelajaran aktif, kreatif, efektif dan menyenangkan. [17] menyatakan bahwa dalam kelas konstruktivis seorang guru tidak mengajarkan kepada anak bagaimana menyelesaikan persoalan, namun mempresentasikan masalah dengan mendorong siswa untuk menemukan cara mereka sendiri dalam menyelesaikan permasalahan. Ketika siswa memberikan jawaban, guru mencoba untuk tidak mengatakan bahwa jawabannya benar atau tidak benar.Namun guru mendorong siswa untuk setuju atau tidak setuju kepada ide seseorang dan saling tukar menukar ide sampai persetujuan dicapai tentang apa yang dapat masuk akal siswa.

Pelajaran matematika adalah pembelajaran abstrak. Pada dasarnya anak belajar melalui benda aktual. Untuk memahami konsep abstrak anak memerlukan benda-benda nyata sebagai perantara atau visualisasinya. Benda-benda kongkrit ini disebut juga dengan benda-benda manipulatif. Benda manipulatif adalah suatu benda yang dimanipulasi oleh guru dalam penyampaian pelajaran matematika agar siswa mudah memahami suatu konsep. [19], mengutarakan berbagai hasil penelitian yang menunjukkan bahwa peran benda manipulatif dalam pembelajaran matematika dapat membantu anak dalam memahami konsep-konsep matematika yang abstrak.

Belajar pakai manipulative mengintensifkan persepsi coret-coretan dan aliansi kemahiran praktek yang berisi mengintensifkan dalih dan penerapannya bagian dalam keadaan penyakit solving yang baru. Pada gilirannya masa yang dihabiskan bagian dalam kursus akal keling dan teladan memasukkan dalih yang periode terbit anutan anak buah dan memperdalam persepsi coret-coretan aritmetika. Melihat sumbangan perkakas manipulatif bagian dalam aritmetika 
sangat penting, kisah selayaknya pelatih selalu mengabdikan perkakas manipulatif bagian dalam kursus di kelas. Hal ini senada dengan rekomendasi NCTM (2000) yang menekankan pentingnya penggunaan penyajian visual dan manipulatif, peragaan model matematika dalam pembelajaran di setiap tingkatan kelas.

\section{KESIMPULAN}

Penerapan matematika begitukuat hubungannya dan kaitannya dengan kehidupan sehar- hari. Jika kita perhatikan lebih luas lagi, seorang ibu sedang memasak air atau memasak sayur itu adalah contoh sederhana dalam penerapan konsep matematika dasar. Matematika pada hakikatnya adalah segala aktivitas manusia di dalam kehidupan sehari-hari. Telah disampaikan bahwa pola pikir matematika sebagai ilmu adalah berpikir efektif. Proses berpikir kreatif siswa berkontribusi dengan pengelaman belajarnya. Banyak salah dasar dari pemahaman konsep dasar dari materi matematika itu sendiri.

\section{DAFTAR PUSTAKA}

[1] Shadiq, F. 2014. Pembelajaran Matematika (Cara Meningkatkan Kemampuan Berpikir Siswa). Yogyakarta: Graha Ilmu.

[2] (UUSPN pasal 1 ayat 1).

[3] Agusdianita, N., \& Asmahasanah, S. (2020). Penyusunan Perangkat Model Quantum Teaching Dalam Pembelajaran Matematika Menggunakan Rme Untuk Meningkatkan Prestasi Belajar, Kreativitas, Dan Karakter Siswa Sd. Attadib Journal Of Elementary Education, 4(1).

[4] Rahmah, N. (2013). Hakikat pendidikan matematika. Al-Khwarizmi: Jurnal Pendidikan Matematika dan Ilmu Pengetahuan Alam, 1(2), 1-10.

[5] Tatag Yuli Eko Siswono, I Ketut Budayasa, Implementasi Teori Tentang Tingkat Berpikir Kreatif dalam Matematika, Jurusan Matematika FMIPA UNESA, 2009, hal. 5-6

[6] Herman, H. (1990). Strategi Belajar Matematika, Malang : IKIP Malang.

[7] Tatag Yuli Eko Siswono, Proses berpikir kreatif...hal. 12 
[8] Harini, Astawa, Srnadi, Eksplorasi miskonsepsi mahasiswa dalam pengembangan buku teks analisis real bermuatan peta pikiran, Jurnal seminar nasional sains dan teknologi, 2014, hal. 943

[9] Muldash, M.P. 2011. Pengembangan Modul Matematika Kontekstual Materi Bangun Datar Kelas V SD. Tesis. Surabaya: Pasca Sarjana Unesa tidak dipublikasikan

[10] Trianto. 2007. Model-model Pembelajaran Inovatif Berorientasi Konstruktivistik. Jakarta:

Prestasi Pustaka

[11] Amir, M. F. (2015, October). Pengaruh pembelajaran kontekstual terhadap kemampuan pemecahan masalah matematika siswa sekolah dasar. In Prosiding Seminar Nasional Pendidikan (pp. 34-42).

[12] Suratno, J. (2013). Program penelitian ethnomathematics dan implikasi langsungnya dalam pembelajaran matematika. Jurnal Penelitian dan Pembelajaran Matematika, 6(2), 137- 143.

[13]Setiawan, A. (2016). Penguatan Peran Matematika dan Pendidikan Matematika dalam Era Masyarakat Ekonomi ASEAN. Jurnal Nasional Sains dan Pendidikan Sains, 6(1), 1-10.

[14] Suwarsono, St. 1998. Peran Strategi Visual dalam Pembelajaran Matematika. Pendidikan Matematika dan Sains: Tantangan dan Harapan. Yogyakarta: Universitas SanataDharma

[15] Widoyoko, E. 2008. Pernanan Dunia Pendidikan Bagi Pengembangan. FKIP Universitas Muhammadiyah Purworejo

[16] Suprijono, Agus. 2009. Cooperative Learning Teori dan Aplikasi PAIKEM. Surabaya:

Pustaka Belajar

[17] Hudoyo, Herman. (1988). Mengajar Belajar Matematika. Jakarta: Depdikbud

[18] Kelly, Catherine A. (2006). Using Manipulatives in Mathematical Problem Solving: A PerformanceBased Analysis. The Montana Mathematics Enthusiast. 
Volume 3, no. 2

[19] Sari, Atikah. (2009). Pemberdayaan Benda Manipulatif Dalam Pembelajaran Matematika Untuk Meningkakan Kemampuan Pemahaman Dan Penalaran Siswa Sekolah Dasar. Tesis. PPS UPI Bandung: Tidak Diterbitkan 